\title{
4p16.3 microduplication syndrome
}

INSERM

\section{Source}

INSERM. (1999). Orphanet: an online rare disease and orphan drug data base. 4 p16.3 microduplication syndrome. ORPHA:96072

4p16.3 microduplication syndrome is a rare genetic syndrome that results from the partial duplication of the short arm of chromosome 4. It has a hig hly variable phenotype, principally characterized by psychomotor and language delay, seizures and dysmorphic features such as high forehead with frontal bossing, hypertelorism, prominent glabella, long narrow palpebral fissures, low set ears and short neck. Eye abnormalities (glaucoma, irregular iris pigmentation, hyperopia) have also been reported. 